\title{
MANAJEMEN PEMBIAYAAN PENDIDIKAN TINGGI DALAM UPAYA PENINGKATAN MUTU (Studi Kasus Pada Perguruan Tinggi Swasta Menengah di Surabaya)
}

\author{
Achmad Anwar Abidin \\ STAI Daruttaqwa Gresik \\ abidelfeiz@yahoo.co.id
}

Diterima 05 Januari 2017, direvisi 24 Januari 2017, diterbitkan 28 Pebruari 2017

\begin{abstract}
Financing a good management is one key to the success of an educational institution to promote or increase quality. In this study, the focus of the problem is how the management of financing available to the private universities in Surabaya medium in order to improve its quality. The method used is qualitative descriptive with the presence of the researcher as an instrument of research conducted interviews to informants as a source of primary data and documents as well as supporting books as a secondary data source. Management Funding education is one of the factors that determine the quality improvement due to the financial management that is transparent and accountable will give rise to the belief of stakehoulder and it will be the motivation of each academicians Tri Dharma College in Private colleges medium in Surabaya to conduct quality improvement in their respective fields.
\end{abstract}

Keyword: management of higher education financing, Quality

\section{PENDAHULUAN}

Pendidikan memiliki peran sentral bagi upaya pengembangan sumber daya manusia, karena dari pendidikan kita bisa merubah cara berpikir dan cara bertindak seseorang dari arah yang tidak baik kearah yang lebih baik dan lebih berguna, dan dari cara berpikir dan bertindak itulah kualitas sumber daya seseorang dapat diketahui.

Kemampuan dalam peningkatan kualitas sumber daya manusia merupakan prasyarat mutlak untuk mencapai visi terwujudnya sistem pendidikan nasional yang berdaya saing tinggi dalam menghadapi era persaingan bebas dunia global.

Pendidikan memanglah patut dan wajib menjadi prioritas utama untuk ditingkatkan. Pendidikan di Indonesia Juga sebagai upaya untuk meningkatkan kualitas sumber daya manusia, sebagai investasi baik bagi individu maupun masyarakat.

Mutu pendidikan tinggi di negera kita masih kalah dibanding Negara-negara tetangga kita di kawasan Asia tenggara. Menurut Maktub (Harian Jogja: 17/11/2016) staf Khusus Kemenristek-dikti Indonesia berada di bawah Singapura dan Malaysia padahal Indonesia merupakan negara dengan sumber daya manusia dan sumber daya alam yang lebih besar dibanding Negara-negara di kawan asia tenggara.

Salah satu elemen penting dalam mutu pendidikan adalah pembiayaan. Pembiayaan kadang juga merupakan inti dari setiap permasalahan pendidikan, apalagi jika dihubungkan dengan Pembiayaan pendidikan 
pada perguruan tinggi swasta yang seluruhnya bersumber dari dana masyarakat walaupun sebenarnya ada bantuan dari pemerintah tetapi tidak terlalu signifikan untuk dibuat acuan dalam penentuan kebijakan maka kualitas pendidikan tinggi swasta tentu sangat bergantung pada bagiamana manajemen pembiayaannya.

Manajemen Pembiayaan yang baik merupakan salah satu kunci dari keberhasilan sebuah lembaga pendidikan untuk memajukan atau meningkat kualitasnya. Dalam penelitian ini fokus permasalahannya adalah bagaimana manajemen pembiayaan yang ada pada perguruan tinggi swasta menengah di Surabaya dalam upaya meningkatkan kualitasnya. Metode penelitian yang digunakan adalah Kualitatif deskriptif dengan kehadiran peneliti sebagai instrument penelitian yang melakukan wawancara kepada informan-informan sebagai sumber data primer dan kemudian dokumendokumen serta buku-buku penunjang sebagai sumber data sekunder.

\section{PEMBAHASAN}

\section{A. Manajemen Pembiayaan Pendidikan Tinggi}

Kata Manajemen berasal dari bahasa latin, yaitu kata manus dan agree yang berarti malakukan. Kata-kata itu digabung menjadi kata kerja managere yang artinya menangani. Managere diterjemahkan dalam bahasa inggris dalam bentuk kata kerja to manage, dengan kata benda dengan management. Kemudian menjadi manajemen dalam bahasa Indonesia yang artinya menurut kamus besar bahasa Indonesia adalah penggunaan sumber daya secara efektif untuk mencapai sasaran.

Dalam dunia pendidikan terdapat manajemen pembiayaan pendidikan karena pembiayaan merupakan hal yang sangat penting untuk berjalannya sebuah lembaga pendidikan di masa sekarang yang dalam hal ini pemerintah juga mengaturnya dalan UU No. 20 Tahun 2003 tentang sistem pendidikan Nasional pasal
11 ayat 2 yang mewajibkan pemerintah dan pemerintah daerah menjamin tersedianya dana guna terselenggaranya pendidikan.

a. Macam-macam biaya pendidikan

Biaya dalam dunia pendidikan memiliki cakupan luas, yaitu setiap jenis pengeluaran yang berkaitaan dengan penyelenggaraan pendidikan, baik dalam bentuk uang maupun barang dan jasa. Pembiayaan pendidikan merupakan proses dalam merencanakan, memperoleh, mengalokasikan dan mengelola biaya yang berkaitan dengan penyelenggaraan proses pendidikan yang akan dan sedang dijalankan. Dalam hal ini meliputi biaya investasi, biaya operasi dan biaya personal.

Biaya investasi meliputi : (1). biaya penyediaan sarana dan prasarana, (2). pengembangan sumberdaya manusia, dan (3). modal kerja tetap.

Biaya operasi meliputi : (1). gaji pendidik dan tenaga kependidikan serta sagala tunjangan yang melekat pada gaji (2). Bahan atau peralatan habis pakai dan biaya pendidikan tak langsung berupa daya, air, jasa telekomunikasi, pemeliharaan sarana dan prasarana, uang lembur, transportasi, konsumsi, pajak, asuransi,dan lain-lain.

Sedangkan biaya personal yaitu biaya pendidikan yang harus dikeluarkan oleh peserta didik untuk bisa mengikuti proses pembelajaran secara teratur dan berkelanjutan.

Menurut Blocher (2013) langkah pertama yang sangat penting dalam konsep dasar manajemen biaya untuk memperoleh keunggulan kompetitif adalah mengidentifikasi biaya dan penggerak biaya utama dalam perusahaan atau organisasi untuk mencapai tujuan yang telah dicanangkan sebelumnya.

b. Sumber Pembiayaan pendidikan

Adapun sumber pembiayaan pada sebuah lembaga pendidikan secara garis besar dapat dikelompokkan menjadi dua sumber, yaitu: 
1) Pemerintah.

Pemerintah bertanggungjawab secara penuh dalam pemenuhan hak mendapatkan pendidikan bagi masyarakat, karena hal itu merupakan amanat dari konstitusi negara kita. Pemerintah pusat dan daerah mempunyai kewajiban yang sama untuk menganggarkan dana pendidikan pada anggaran belanja mereka.

Adapun besarnya biaya pendidikan yang dibebankan pada pemerintah sesuai amanat Pasal 31 ayat (4) Undang-Undang Dasar Negara Republik Indonesia Tahun 1945 yang telah diamandemen adalah sebesar 20 $\%$ dari Anggaran pendapatan dan belanja Negara pada masa tahun anggaran berjalan dan kebijakan 20\% ini tidak dalam lingkup nasional semata tetapi juga dari anggaran APBD untuk propinsi dan pemda kabupaten/kota untuk pendidikan dasar baik jalur sekolah maupun non sekolah sesuai PP nomor 48 tahun 2008 tentang pendanaan pendidikan.

2) Orang tua/wali/Mahasiswa dan masyarakat

Sumber pembiayaan yang kedua ini biasanya berupa Sumbangan Pembinaan Pendidikan (SPP), uang gedung dan lain-lain yang sesuai dengan peraturan yang berlaku dan sumber pembiayaan ini adalah mutlak bagi lembaga pendidikan swasta.

\section{B. Perencanaan Pembiayaan(Budgeting) Pendidikan tinggi Swasta}

Perencanaan sangatlah dibutuhkan untuk mencapai tujuan yang lebih optimal karena perencanaan itu sendiri adalah proses penentuan tujuan atau sasaran yang hendak dicapai dan menetapkan jalan dan sumber yang diperlukan untuk mencapai tujuan itu seefesien dan seefektif mungkin (Fattah:2012) apalagi dalam dalam proses perencanaan pembiayaan.

Menurut Made Pidarta (2011) suatu pekerjaan dikatakan efektif ialah kalau pekerjaan itu memberi hasil yang sesuai dengan kriteria yang ditetapkan semula, dengan kata lain kalau pekerjaan itu sudah mampu merealisasi tujuan organisasi dalam aspek yang dikerjakan itu.Sedangkan efesien adalah Pekerjaan yang menghabiskan biaya sesuai dengan rencana semula atau lebih rendah.

Kemudian Budget atau Anggaran merupakan rencana terperinci untuk pemerolehan dan pemakaian sumber daya keuangan dan lain-lain selama periode waktu tertentu-khususnya satu tahun fiskal. Anggaran mencakup seluruh aspek baik keuangan maupun non keuangan dari kegiatan yang akan dilaksanakan dan dijadikan sebagai pedoman operasional pada kurun waktu yang dianggarkan.dan proses penyiapan atau penyusunan ini disebut penganggran atau budgeting.

Dalam menentukan anggaran sebaiknya bertumpu pada faktor efesiensi dan efektivitas karena hanya dengan perencanaan yang efesien dan efektiflah dapat diciptakan sebuah nilai tambah.

Fungsi dasar suatu anggaran adalah sebagai alat perencanaan (planning), alat koordinasi (coordinating) dan alat pengendalian (Controlling).

Seperti yang terjadi dalam perusahaanperusahaan dalam prosedur penyusunan anggaran hal-hal yang perlu diperhatikan adalah, tujuan dan sasaran, kebijakan, dan asumsiasumsi faktor eksternal. Dalam pembiayan pendidikan pun hampir sama pada acuan-acuan tersebut.

Langkah-langkah penyusunan anggaran yaitu:

1). Menginventarisasi rencana yang akan dilaksanakan

2). Menyusun rencana berdasar skala prioritas pelaksanaannya 
3). Menentukan program kerja dan rincian program

4). Menetapkan kebutuhan untuk pelaksanaan rincian program

5). Menghitung dana yang dibutuhkan

6). Menentukan sumber dana untuk membiayai rencana.

Dalam pelaksanaan kegiatannya, jumlah yang direalisasikan bisa jadi tidak sama dengan anggarannya. Realisasi keuangan yang tidak samadengan anggaran harus dianalisis penyebabnya, dan apabila diperlukan dapat dilakukan revisi anggaran agar fungsi anggaran dapat tetap berjalan. Perbedaan antara realisasi pengeluaran dengan anggarannya bisa terjadi karena:

1). Adanya efisiensi atau inefisiensi pengeluaran

2). Terjadinya penghematan atau pemborosan

3). Pelaksanaan kegiatan yang tidak sesuai dengan yang telah diprogramkan

4). Adanya perubahan harga yang tidak terantisipasi

5). Penyusunan anggaran yang kurang tepat.

Anggaran bersifat luwes artinya apabila dalam perjalanan pelaksanaan kegiatan ternyata harus dilakukan penyesuaian kegiatan, maka anggaran dapat direvisi dengan menempuh prosedur tertentu.

Menurut Loeloek (2013) perhitungan biaya pendidikan berdasarkan pendekatan kecukupan ditentukan oleh beberapa faktor ,diantaranya :

1) Besar kecilnya sebuah institusi pendidikan

2) Jumlah peserta didik

3) Tingkat gaji tenaga pendidik dan Karyawan

4) Rasio peserta didik dibanding jumlah guru/dosen

5) Kualifikasi tenaga pendidik
6) Tingkat pertumbuhan populasi penduduk

7) Perubahan dari pendapatan.

Dari paparan diatas utuk merealilsasikan tujuan lembaga maupun program yang telah direncanakan dalam jangka pendek maupun dalam jangka panjang memerlukan sumber daya manusia dan ketersediaan dana oleh karena itu penganggaran sangatlah penting bagi organisasi non-profit dalam mengaktualisasikan perencanaan, karena tidak saja berkenaan dengan masalah penerimaan, penyimpanan, penggunaan dan pertangjawabannya.

Dalam hal ini maka setiap perguruan tinggi perlu menyusun penganggaran (budgeting) Rencana Anggaran Perbelanjaan Biaya Perguruan Tinggi (RAPBPT) untuk memutuskan strategi dalam mencapai visi dan misi dari perguruan tinggi karena budgeting merupakan rencana terperinci untuk pemerolehan dan pemakaian sumber daya keuangan dan lain-lain selama periode tertentu. Dan RAPBPT tersebut harus selaras dengan visi misi perguruan tinggi tersebut yang telah dituangkan dalam statuta, dicanangkan pada Rencana Induk Pengembangan dan Rencana Strategis (Renstra) sebagai arah dan tujuan akan dibawa kemana atau dibagaimanakan perguruan tinggi tersebut.

Dalam menentukan biaya kita harus menimbang beberapa hal diantaranya; waktu, fungsi dan harga. Waktu: yaitu lama dari kegiatan atau program, Fungsi : yaitu misalnya gaji dan honorarium yang berkaitan dengan fungsi ketenagaannya, dan Harga: yaitu berkaitan dengan harga-harga barang dalam kaitannya dengan sebuah kegiatan atau program. Dan pada saat penentuan besaran biaya ini sebaiknya seluruh pemangku kepentingan di perguruan tinggi semua dipertemukan untuk memusyawarahkannya sehingga terjadi keterbukaan dan terhindar dari konflik yang mungkin dapat timbul setelahnya. 
a. Tahapan- tahapan dalam perencanaan

Adapun langkah-langkah dalam tahapan perencanaan menurut Guruge dalam Sarbini (2012) secara garis besar adalah Sebagai berikut:

1. Tahap Pra Rencana

Tahapan ini adalah tahap awal sebelum memulai perencanan, dalam tahap ini langkah-langkah yang perlu dilakukan adalah:

a) pembentukan organisasi perencanaan yang sesuai

b) penentuan prosedur perencanaan

c) reorganisasi structural mengenai mesin administrative pendidikan untuk berpartisipasi dalam perumusan dan implementasi rencana.

d) Menentukan mekanisme dan prosedur untuk mengumpulkan dan menganalisis data statistis dan lain-lainnya yang diperlukan bagi perencanaan

2. Tahap perencanaan

Dalam tahapan ini terdapat enam langkah pokok yang harus dilaksanakan, meliputi :

a) Diagnosis, dimaksud untuk mengidentifikasi kelemahan dan kekurangan dalam sifat, luas, organisasi serta tingkat aktivitasaktivitas pendidikan, dan menekankan pada tiga kriteria yakni: relevansi, (sesuai dengan kebutuhan ). efektivitas (tercapainya tujuan) dan efesiensi ( dapat menggunakan segala sumber daya yang ada untuk mencapai tujuan yang maksimal)

b) Perumusan kebijakan, merumuskan arah kebijakan yang akan diambil selanjutnya

c) Perkiraan kebutuhan masa depan, diarahkan pada antisipasi pada kebutuhan di masa yang akan datang

d) Pembiayaan kebutuhan masa depan, menetapkan biaya bagi kebutuhan di masa depan

e) Penentuan prioritas dan seperangkat sasaran, menentukan yang paling prioritas agar dapat menentukan alokasi biaya yang paling relevan dan efektif

f) Uji kelayakan, diperlukan untuk menjamin keberlangsungan.

3. Tahap perumusan rencana

Dalam tahap ini langkah yang harus dilakukan adalah :

a) Menyajikan seperangkat keputusan mengenai perencanaan kegiatan yang akan dilaksanakan

b) Menyiapkan blue print tindakantindakan atas konsekuensi dari keputusan-keputusan tersebut

4. Tahap elaborasi rencana

Ada dua langkah dalam proses penjabaran atau proses elaborasi ini yakni:

a) Programming, biasanya meliputi semua aktivitas yang disupervisi oleh unit administratif yang sama atau yang saling tergantung dan saling melengkapi, dimana semua harus dikerjakan secara simultan atau berurutan

b) Identifikasi dan perumusan proyek, untuk menetukan tujuan yang lebih spesifik atau target dalam tujuan utama dari suatu program

5. Tahap implementasi rencana

Pada tahap ini adalah eksekusi dari rencana yang telah dibuat, menggunakan anggaran tahunan atau rencana tahunan sebagai instrumen kemudian segala sumber daya ayang diperlukan dialokasikan, waktu yang 
diperlukan telah ditentukan, adanya pendelegasian wewenang, garis komunikasi dan konsultasi serta pemberian tanggunag jawab dan instalasi umpan balik serta meknisme control dilaksanakan pada tahapan ini.

6. Tahap evaluasi, revisi dan perencenaan kembali

Pada tahapan ini adalah tahap terakhir daur perencanaan yang dijadikan sistem yang berkesinambungan dalam arti bahwa pada tahap ini adalah tahap akhir sekaligus tahap awal bagi proses perencanaan selanjutnya yang berfungsi sebagai alat untuk mengukur keberhasilan dari perencanaan yang telah dilaksanakan sebelumnya.

\section{Pengorganisasian Pembiayaan Pendidikan Tinggi}

Perguruan tinggi menentukan kebijakan dan memiliki otonomi dalam mengelola pendidikan dan lembaganya, hal ini terutang dalam Undang - undang Sisdiknas no 20 tahun 2003 pasal 50 ayat 5. Tentunya dalam hal ini juga meliputi pengelolaan pembiayaannya jadi tidak ada aturan baku dari pemerintah dalam tata laksana pengolaannya.

Sebenarnya tahap kedua dari proses kegiatan pembiayaan ini adalah pembukuan atau kegiatan pengurusan keuangan atau lazimnya disebut pengeloaan pembiayaan. Pengurusan keuangan ini meliputi dua hal yaitu, pertama pengurusan yang menyangkut kewenangan menentukan kebijakan menerima atau mengeluarkan uang.Pengurusan ini dikenal dengan istilah pengurusan ketatausahaan.

Pengurusan kedua menyangkut kegiatan bendaharawan dalam administrasi keuangan dalam arti sempit (tata usaha keuangan), diwujudkan berupa penerimaan, pencatatan, penyimpanan, penggunaan/pembayaran dan pertanggungjawaban.

Pengelolaan dana bukan hanya sekedar mengarah pada penyelenggaraan pendidikan yang efektif dan efisien, tetapi juga dengan dana tersebut perguruan tinggi harus mampu meningkatkan mutu lulusannya dan mampu bersaing dengan perguruan tinggi yang lainnya. Dalam Pasal 48 ayat (1) UU No. 20 Tahun 2003 tentang Sistem Pendidikan Nasional menyebutkan bahwa "Pengelolaan dana pendidikan berdasarkan prinsip keadilan, efisiensi, transparansi, dan akuntabilitas publik".

Keadilan maksudnya bahwa dana yang disediakan oleh pemerintah untuk keperluan pendidikan berasal dari masyarakat melaui pajak dan pungutan-pungutan lain. Oleh karena itu harus dapat digunakan untuk kepentingan masyarakat untuk memperoleh pendidikan secara adil. Yang dimaksud adil yaitu mengusahakan semua anggota masyarakat mendapat kesempatan memperoleh pendidikan yang sama, baik bagi mereka yang cacat, terbelakang, tidak mampu, maupun yang normal dan kaya.

Efisiensi maksudnya harus dilaksanakan di semua instansi, termasuk dalam bidang pendidikan, Terutama dalam penyelenggaraan pendidikan itu sangat terbatas.Efisiensi selalu membandingkan dua hal, yaitu masukkan dengan keluaran. Dalam hal ini biaya pendidikan dapat mengukur efisiensi dengan membandingkan cost dengan outcome.

Dari uraian di atas maka diperlukanlah pengorganisasian pembiayaan yang dimaksud dengan pengorganisasian disini yaitu proses pengorgainsasian sebagai salah satu cara dimana kegiatan organisasi dialokasikan dan ditugaskan diantara para anggotanya agar tujuan organisasi dapat tercapai dengan efektif dan efesien.

Dalam sebuah pengorganisasian diperlukan struktur organisasi sebagai mekanisme formal pengelolaan organisasi, yang menunjukkan susunan perwujudan dari sebuah pola organisasi yang terkait hubungan-hubungan diantara fungsi-fungsi, bagian-bagian atau posisi-posisi yang menunjukan kedudukan, 
tugas, wewenang dan tanggung jawab yang berbeda-beda.

Ada dua aspek utama proses penyusunan struktur organisasi untuk mencapai tujuan yang telah di tetapkan secara efesien dan efektif adalah :

1) Pengelompokan kegiatan-kegiatan kerja suatu organisasi agar kegiatankegiatan yang sejenis dan saling berhubungan dapat di lakukan secara bersama.

2) Pembagian kerja, yaitu rincian tugas pekerjaan agar setiap individu dalam organisasi bertanggung jawab untuk melaksanakan sekumpulan kegiatan yang terbatas pada bagian-bagian tertentu yang merupakan bagian terkait dari keseluruhan sistem yang ada.

Pengorganisasian keuangan di sebuah lembaga pendidikan biasanya diatur oleh seorang Manajer Keuangan, dan seorang manajer keuangan harus memahami prinsip pengelolaan keuangan yang baik, yaitu prinsip terarah dan terkendali sesuai dengan rencana, program, atau kegiatan yang ada (Zuhroh:2015).

Selanjutnya seorang manajer keuangan tersebut mengatur setiap sumber daya yang ada berupa sumber daya manusia (Staff) pada lembaga pendidikan tersebut dalam rangka untuk melakukan perencanaan pembiayaan pada program atau kegiatan dan melakukan pelaporan.

Pelaporan pembiayaan yang dimaksud dalam hal ini adalah auditing yaitu semua kegiatan yang menyangkut pertanggungjawaban penerimaan, penyimpanan dan pembayaran atau penyerahan uang yang dilakukan bendaharawan kepada pihak-pihak yang berwenang.

Kegiatan ini adalah membuat laporan pertanggungjawaban keuangan kepada kalangan internal lembaga atau eksternal yang menjadi stakeholder lembaga pendidikan. Pelaporan pertanggung jawaban sesuai dengan ketentuan yang berlaku agar semua dana benarbenar di manfaatkan secara efektif, efesien, tidak ada kebocoran-kebocoran, serta bebas dar penyakit korupsi, kolusi, dan nepotisme.

\section{Peningkatan Mutu Pendidikan Tinggi Pada Kampus Swasta Menengah di Surabaya}

Dalam konteks pendidikan, pengertian mutu mencakup tiga aspek dasar yang sangat perlu diperhatikan yaitu meliputi; masukan (input), proses pendidikan, dan keluaran (output) pendidikan.

Masukan (input) adalah segala sesuatu yang harus tersedia karena dibutuhkan untuk berlangsungnya proses dalam hal inilembaga perguruan tinggi setidaknya melakukan tiga hal yang biasa disebut dengan Tri Dharma perguruan tinggi yaitu: pendidikan, penelitian, dan pengabdian kepada masyarakat.

Adapun input layanan dalam bidang pendidikan antara lain:

1. Mahasiswa

Layanannya meliputi : sistem penerimaan mahasiswa, proses penerimaan mahasiswa,dan registrasi.

2. Program studi

Layanan program studi meliputi: Prodi S-1, Prodi S-2, Prodi S-3 dengan berbagai cabang keilmuan yang diminati

3. Dosen

Layanan dosen meliputi : penyediaan dosen sesuai kualifikasi, penyediaan rasio dosen sesuai jumlah mahasiswa, pengembangan kompenti dosen

4. Tenaga kependidikan

Layanan tenaga kependidikan meliputi : rasio jumlah tenaga administrasi, rasio jumlah teknisi/laboran, rasio jumlah pustakawan

5. Sarana prasarana

Layanan sarana prasarana meliputi : ruang kuliah, ruang dosen, ruang administrasi, perpustakaan, 
laboratorium, bahan dan alat praktek per-prodi dan adanya teknologi pendidikan

6. Pembiayaan

Pembiyaan meliputi : pembiayaan dari mahasiswa, dari pemerintah, dari kerja sama, hibah dll.

7. Proses pembelajaran

Proses pembelajaran meliputi : kurikulum, perkuliahan, dan penilaian.

Sedangkan input dalam bidang pelitian antara lain :

1. Dosen meliputi : jumlah dosen yang terlibat dalam penelitian, rasio dosen yang terlibat dalam penelitian dan jumlah total dosen

2. Sarana prasarana meliputi : penyediaan sarana penelitian, dan penyediaan sisteminformasi penelitian

3. Dana meliputi : prosetase dana penelitan dan kerjasa sama, jumlah dana riset per- dosen

Input dalam bidang pengabdian kepada masyarakat antara lain :

1. Dosen meliputi : jumlah pengabdian masyarakat, jumlah dosen yang terlibat dalam pengabdian masyarakat,rasio jumlah dosen yang terlibat dalam pengabdian masyarakat dengan total dosen

2. Sarana prasarana meliputi : penyediaan dana dan penyediaan sisteminformasi

Kesiapan input sangat diperlukan agar proses dapat berlangsung dengan baik. Oleh karena itu, tinggi rendahnya mutu input dapat diukur dari tingkat kesiapan input.Makin tinggi tingkat kesiapan input, makin tinggi pula mutu input tersebut.

Proses pendidikan merupakan berubahnya sesuatu menjadi sesuatu yang lain. Sesuatu yang berpengaruh terhadap berlangsungnya proses disebut input, sedang sesuatu dari hasil proses disebut output. Dalam pendidikan bersekala mikro, proses yang dimaksud adalah proses pengambilan keputusan, proses pengelolaan kelembagaan, proses pengelolaan program, proses belajar mengajar, dan proses monitoring dan evaluasi, dengan catatan bahwa proses belajar mengajar memiliki tingkat kepentingan tertinggi dibandingkan dengan proses-proses lainnya.

Output pendidikan adalah merupakan kinerja lembaga.Kinerja lembaga adalah prestasi lembaga yang dihasilkan dari proses/ perilaku lembaga.Kinerja lembaga dapat diukur dari kualitasnya, efektivitasnya, produktivitasnya, efisiensinya, inovasinya, kualitas kehidupan kerjanya, dan moral kerjanya.Mutu lembaga dipengaruhi oleh banyak tahapan kegiatan yang saling berhubungan (proses) seperti misalnya perencanaan, pelaksanaan, dan pengawasan.

Adapun output dari perguruan tinggi yang melasanakan Tri Dharma perguruan tinggi adalah output pendidikan, output penelitian dan output pengabdian kepada masyarakat.

Output pada bidang pendidikan dan pengajaran meliputi : IPK Lulusan, Lama studi, masa tunggu, kompetensi bahasa, dan wadah alumni. Sedangkan output pada bidang penelitian antara lain : laporan penelitian yang meliputi: publikasi penelitian, dan diseminasi hasil penelitian. dan jumlah HAKI/Paten yang dihasilkan dari penelitian. Kemudian output dalam bidang pengabdian kepada masyarakat adalah laporan penelitian yang berkaitan dengan pengabdian kepada masyarakat.

Dalam proses pendidikan di perguruan tinggi penjaminan mutu merupakan perwujudan dari akuntabilitas perguruan tinggi terhadap hakhak masyarakat terutama para stakehodernya sendiri dan merupakan sebuah keharusan untuk menjaga kepercayaan publik.

Penjaminan mutu merupakan cara mengatur semua kegiatan dan sumber daya pendidikan yang diarahkan pada kepuasan pelanggan. Semua orang yang terlibat dalam proses pendidikan melaksanakan tugas dengan penuh semangat dan berpatisipasi dalam 
perbaikan layanan pendidikan sehingga dapat memberikan layanan yang sesuai atau melebihi harapan pelanggan.

Penjaminan mutu internal (internal quality assurance) adalah sistem penjaminan mutu pendidikan yang di lakukan oleh internal lembaga pendidikan itu sendiri, bentuknya berupa evaluasi diri yang dilakuakan oleh program studi atau institusi perguruan tinggi tujuannya untuk memperbaiki kinerja dan memberi penjaminan mutu internal khususnya kepada para stakeholder internal perguruan tinggi, seperti para pimpinan, dosen, peneliti, karyawan dan mahasiswa.

Ada banyak bentuk pengembangan sistem penjaminan mutu di tiap-tiap perguruan tinggi di Indonesia, ada perguruan tinggi yang mengembangkan organisasi internal berbentuk lembaga atau badan namun ada pula yang sama sekali tidak mengembangkan sistem dan tidak mendirikan organisasi.

Sebenarnya sistem mutu terpadu dan sistem penjaminan mutu baik internal maupun eksternal tidak akan berdampak terhadap perbaikan mutu di sebuah perguruan tinggi apabila tidak dipadukan menjadi satu daur dengan sisstem perbaikan mutu berkelanjutan, jadi dengan kata lain menjadikan sistem penjaminan mutu dan perbaikan mutu berkelanjutan menjadi satu daur yang kemudian daur tersebut dilakukan secara terus menerus untuk memperoleh perbaikan mutu secara optimal.

Faktor-faktor atau indikator yang dijadikan acuan dalam peningkatan Mutu pada sebuah perguruan tinggi antara lain :

1. Tata Kelola/Administrasi

Tata kelola/Administrasi yang baik adalah aspek utama dalam penilaian mutu karena Admintrasi adalah kegiatan atau rangkaian kegiatan sebagai proses pengendalian usaha kerjasama sekelompok manusia untuk mencapai tujuan bersama yang telah ditetapkan sebelumnya.
Beberapa hal yang dapat dijadikan bahan pertimbanganterkait dengan sistem tata kelola suatu institusi pendidikan adalah:

a. Pimpinan institusi dan pimpinan level di bawahnyamutlak harus memiliki kemampuan leadership dankemampuan pendukung lainnya. Karena pemimpin sebagai penggerak manejemen

b. Adanya kejelasan wewenang dan tanggung jawab tiap jabatan dalam institusi pendidikan.

c. Kepemimpinan dievaluasi secara berkala dalamhal pencapaian visi, misi dan tujuan suatu institusi pendidikan.

d. Adanya dasar yang jelas dalam berkomitmen terhadap institusi.

e. Civitas akademika khususnya pejabatinstitusi memiliki tanggung jawab yang sama dalam menciptakan suasana pembelajaran yang kondusif secara psikis.

f. Pimpinan mampu memotivasi orang-orang yang dipimpin untuk selalu bekerja dengan berorientasi pada visi, misi dan tujuan institusi.

g. Adanya sistem reward dan punishment untukmendorong kinerja yang lebih baik.

2. Pengabdian pada Masyarakat

Pengabdian kepada masyarakat dilakukan sebagaibentuk tanggung jawab sosial suatu institusipendidikan terhadap masyarakat karena bagian dari Tri dharma perguruan tinggi. Agar pengabdian masyarakat dapat dilakukan dengan baik, dapat diperhatikan beberapa hal berikut :

a. Kegiatan ini sebaiknya dilakukan dengan dasar memberikan manfaat secara luas terhadap masyarakat mengembangkan dan memanfaatkan ilmu pengetahuan yang dimiliki. 
b. Pengabdian pada masyarakat hendaknya mampu memberikan umpan balik untuk kepentingan institusi baik untuk proses pembelajaran maupun penelitianpenelitian yang dilakukan.

c. Pengabdian pada masyarakat harus berorientasi pada peningkatan kesejahteraan masyarakat salah satunya dengan menciptakan produk tepat guna dan menyelesaikan permasalahan yang sedang berkembang.

3. Kurikulum Program Studi

Para perancang kurikulum harus menentukan kompetensi apa saja yang harus dimiliki oleh para tamatan program studi yang bersangkutan. Semakin dekat kurikulum institusi dengan kebutuhan dunia kerja, maka kualitas lulusan akan semakin baik. Berikut ini adalah beberapa hal yang harus diperhatikan agar institusi pendidikan mampu menyusun kurikulum yang baik:

a. Kurikulum disusun dan dievaluasi secara kontinyu mengingat kebutuhan dunia kerja yang dinamis. Dalam hal ini pihak institusi diharapkan memiliki responsifitas yang tinggi.

b. Kurikulum disusun berbasis kompetensi dans elalu update.

c. Kurikulum yang disusun mampu menghasilkan lulusan yang bertanggung jawab terhadapkemajuan bangsa dan senantiasa ingin mengembangkan keilmuan yang dimiliki.

4. Proses Pembelajaran.

Proses pembelajaran pada satuan pendidikan diselenggarakan secara inspiratif, menyenangkan, menantang, memotivasi untuk berpartisipasi aktif serta memberikan ruang yang cukup bagi prakarsa, kreativitas, dan kemandirian sesuai dengan bakat, minat, dan perkembangan fisik serta psikologis.

Dalam mengembangkan suatu proses pembelajaran dapat dipertimbangkan hal-hal berikut :

a. Pembelajaran tidak hanya difokuskan pada pengembangan intelektualitas mahasiswa sesuaidisiplin ilmu, namun perlu diimbangi denganpengembangan soft skill mahasiswa

b. Adanya objektivitas dan sistem evaluasi hasil studi yang transparan didukung dengan adanya umpan balik dari dosen mengenai hasil evaluasi itusendiri.

c. Proses pembelajaran sebaiknya merupakan proses dua arah yang melibatkan komponen dosen danmahasiswa sehingga ada timbal balik dalam transfer ilmu pengetahuan antara keduanya.

5. Sumber Daya Manusia

Berikut adalah beberapa hal yang kiranya dapat diperhatikan berkaitan dengan Sumber Daya Manusia:

a. Dosen :

1) Sistem rekrutmen dan pengembangan dosen disesuaikan dengan kebutuhan kurikulum baik untuk kualifikasi, terutama soft skill yang dimiliki.

2) Mampu menyusun program pembelajaran yang berkelanjutan, rasional dan relevan dengan kebutuhan dunia industri secara up date.

3) Adanya promosi dosen yang dilakukan secara objektif berdasarkan prestasi dan pengabdian baik dari sisi pengajaran, penelitian dan 
publikasi, serta pengabdian kepada masyarakat.

4) Adanya job description yang jelas meliputi materi pembelajaran dan beban kerja.

b. Tenaga kependidikan/Karyawan : Tenaga kependidikan pada pendidikan tinggi harus memiliki kualifikasi, kompetensi, dan sertifikasi sesuai dengan bidang tugasnya.

1) Sistem rekrutmen dan pengembangan karyawan disesuaikan dengan kebutuhan pelaksanaan program pembelajaran baik untuk kualifikasi, terutama soft skill yang dimiliki.

2) Adanya promosi karyawan yang dilakukan secara objektif berdasarkan prestasi dan pengabdian.

3) Adanya job description yang jelas meliputi tugas dan pekerjaan yang harus dilaksanakan beikut beban kerja.

6. Suasana Akademik

Berikut beberapa hal yang dapat dipertimbangkan dalam menciptakan suasana akademik yangmendukung:

a. Adanya perencanaan pemenuhan kebutuhan sarana dan alokasi dana dalam rangka mendukungterciptanya suasana akademik yang dibutuhkan.

b. Civitas akademika hendaknya memiliki tanggung jawab yang sama dalam menciptakan suasana proses pembelajaran yang harmonis, nyaman,saling menghargai dan saling menghormati sehingga tercipta suasana pembelajaran yangmendukung. c. Adanya kebijakan untuk memberikan penghargaan dan sanksi agar masing-masing civitas akademikamemiliki tanggung jawab yang besar untukbersamasama menciptakan suasana yang nyamandan mendukung proses pembelajaran.

7. Penelitian dan Publikasi

Beberapa hal yang dapat dipertimbangkan untuk menghasilkan penelitian dan publikasi yang optimal baik dari segi jumlah maupun kualitas adalah:

a. Penelitian sebaiknya lebih banyak melibatkan mahasiswa.

b. Penelitian yang dilakukan harus memenuhi standar mutu baik untuk tingkat nasional maupun internasional.

c. Hasil penelitian mampu mendukung pengembangan ilmu pengetahuan, mendukung kebijakan pemerintah dan memperkaya kasanah keilmuan dunia pendidikan.

d. Pihak institusi mendorong dilakukannya penelitian baik dari segi jumlah maupun kualitas penelitian itu sendiri secara kontinyu.

e. Adanya penghargaan bagi peneliti baik berdasarkan cakupan penelitian maupun jumlahdan kualitas penelitian.

f. Menjalin kerja sama dengan dunia industri baik dalam hal pendanaan maupun objek penelitian.

g. Hasil penelitian dipublikasikan dan dapat diakses secara luas oleh masyarakat sesuai dengan kebutuhan.

h. Menjalin kerjasama baik antar jurusan maupun dengan pihak institusi lain untuk dapat menghasilkan penelitian yang semakin berkualitas. 
8. Kemahasiswaan

Berikut terdapat beberapa hal yang dapat dipertimbangkan untuk mendukung kegiatan kemahasiswaan antara lain :

a. Pihak institusi sedapat mungkin mendorong mahasiswa untuk memiliki peranan dalam satuatau lebih organisasi kemahasiswaan.

b. Menyediakan fasilitas pendukung kegiatan ekstrakurikuler seperti ruangan, tenaga pendidik/pelatih dan peralatan.

c. Kegiatan kemahasiswaan yang dilakukan hendaknya mampu meningkatkan kompetensi lulusan.

d. Pihak institusi secara aktif menjalin kerja samadengan pihak industri (perusahaan) dalam memberikan dukungan dana maupun untuk kegiatan magang mahasiswa.

9. Manejemen Pembiayaan

Faktor ini sangat signifikan karena melibatkan pihak internal manajemen institusi terkait dengan biaya yang dibutuhkan untukdapat menyelenggarakan pembelajaran yang bermutu, karena setiap hal yang dilakukan guna untuk meningkatkan kualitas pendidikan tinggi membutuhkan pembiayaan yang tinggi pula.

Disisi lain juga tingginya biaya yang dibutuhkan mengakibatkan mahasiswa atau calon mahasiswa akan menanggung biaya pendidikan yang tinggipula.

Dalam hal ini ada Beberapa masukan yang dapat diberikan antara lain :

a. Penetapan besar biaya pendidikan yang harusdikeluarkan mahasiswa harus berada dalam batas kewajaran dan memperhatikan faktor kebutuhan.

b. Adanya evaluasi secara berkala terhadap besaran biaya pendi- dikan yang harus dikeluarkan mahasiswa.

c. Pihak institusi mengembangkan kerja sama saling menguntungkan dengan pihak industri untuk mendukung pembiayaan pendidikan.

d. Pengalokasian dana sebaiknya disesuaikan dengan prioritas kebutuhan dan berorientasi padapeningkatan mutu.

e. Adanya pertanggungjawaban pengunaan danasecara berkala.

10. Prasarana dan Sarana

Beberapa hal yang dapat dijadikan masukan antara lain:

a. Pihak institusi memiliki prioritas pengembangan prasarana dan sarana sesuai target capaian yang dimiliki.

b. Adanya tanggung jawab bersama seluruh civitas akademika terhadap pemeliharaan prasarana dan sarana.

c. Prasarana dan sarana yang disediakan harus dapat diakses oleh seluruh civitas akademika.

d. Prasarana dan sarana yang dimiliki hendaknya memenuhi persyaratan teknis baik dari segi luas (bangunan), jumlah, kualitas dan kontinuitas pemeliharaannya.

\section{SIMPULAN}

Perencanaan pembiayaan pendidikan di kampus swasta menengah di Surabaya sebagai proses pertama dalam manajemen pembiayaan melalui tahapan-tahapan yang harus dilalui yaitu :Tahap Pra Rencana ,tahap perencanaan, tahap perumusan rencana, tahap elaborasi rencana, tahap implementasi rencana dan tahap evaluasi, revisi dan perencenaan kembali yang masingmasing tahapan tersebut di rapatkan bersama, 
sampai pada membuat RAB yang kemudian akan diserahkan kepada yayasan/pengelola sebagai penyelenggara pendidikan. Setelah ada assessment dari yayasan melalaui rapat yayasan barulah kemudian RAB itu disahkan untuk dijalankan sesaui tahun anggaran.

Manajemen Pembiayaan pendidikan menjadi salah satu faktor yang menentukan dalam peningkatan mutu dikarenakan dengan manajemen pembiayaan yang transparan dan akuntabel maka akan timbul kepercayaan dari stakehoulder dan itu akan menjadi motivasi dari setiap civitas akademika Tri Dharma Perguruan Tinggi pada perguruan tinggi swasta menengah di surabay untuk melakukan peningkatan mutu dalam bidangnya masingmasing.

\section{DAFTAR PUSTAKA}

Aedi,Nur, Dasar-Dasar Manajemen Pendidikan, Pustaka Cendikia Utama, Bandung, 2012

Blocher, Edward J., David E. Stout, Paul E. Juras and Gary Cokins. "Cost Management: A Strategic Emphasis". 6th edition. McGraw-Hill International Edition. 2013
Fattah, Nanang, Standar Pembiayaan Pendidikan.Bandung :PT. Rosdakarya 2012

Hanif Saha Ghafur, Manajemen Penjaminan Mutu Perguruan Tinggi Di Indonesia, bumi Aksara, Jakarta, 2010

Loeloek Endah P, Sofan Amri, Panduan Memahami Kurikulum 2013, Prestasi Pustaka Karya, Jakarta,2013

Made Pidarta, Manajemen Pendidikan Indonesia, cet.3 Jakarta:Rineka Cipta,2011

Marzuki Mahmud, Manejemen Mutu Perguruan Tinggi,Raja Grafindo : Jakarta, 2012

Matin, Dasar-dasar Perencanaan Pendidikan, Raja Grafindo, Jakarta, 2013

Sarbini, dan Lina, Neneng, Perencanaan Pendidikan, Pustaka Setia, Bandung, 2012

Zuhroh, Aminatuz, Total Quality Management, Arruz Media, Yogyakarta,2015 